\title{
Implementasi Total Quality Management dalam Pengembangan Manajemen Pembelajaran Karakter Religius
}

\author{
Mia Sari \\ Manajemen Pendidikan Islam Universitas Negeri Sunan Kalijaga Yogyakarta \\ Email: miasarims96@gmail.com
}

\begin{abstract}
This paper presents the implementation of Total Quality Management in developing religious character learning management. Total Quality Management as an approach that emphasizes the existence of a continuous improvement effort in maximizing products, services, and human resources. Character learning based on Total Quality Management is a process of transferring, habituating, and forming character values by educators (teachers) to students, which is carried out based on the concept of Total Quality Management, namely: quality, customer satisfaction, continuous improvement, and comprehensive in all organizational components. This research is a library research using a qualitative approach. The results of this study indicate that the implementation of Total Quality Management in the development of religious character learning management is still very much needed for educational institutions, especially in the learning process.
\end{abstract}

Keywords: Al-Qasimi Method, Student, Al-Qur'an

\section{PENDAHULUAN}

Pendidikan agama merupakan fondasi yang kuat dalam menghadapi kehidupan yang menantang saat ini, kebebabasan yang ditunjukkan oleh barat memberikan pandangan bahwa kehidupan saat ini penuh dengan tantangan. Di sadari atau tidak, di sukai atau tidak, pengaruh dari tradisi barat pun sangat mempengaruhi kehidupan (Hikmah:2017). Pendidikan agama diharapkan dapat meningkatkan potensi spiritual pada peserta didik, dari sudut pandang mengenai pendidikan moral dan karakter lebih penting dari pendidkan sekuler (Chowdhury, 2016:5). Persoalan moral tersebut melibatkan anak mulai dari usia termuda. Perilaku mencontek dan berbohong adalah sebagaian contoh dari perilaku moral yang dikemukakan oleh Chaplin (1999). Saat ini banyak dijumpai masalah-masalah dikalangan peserta didik terkait dengan berbagai bentuk kenakalan yang dilakukan remaja, seperti: 
tawuran antar pelajar, bulling, hingga berhubungan seksual dengan lawan jenis (free sex).

Pendidikan karakter diterapkan dalam dunia pendidikan untuk menciptakan generasi muda yang bermartabat guna mencerdaskan kehidupan bangsa dan bertujuan menjadi beriman yang bertakwa, berbudi luhur, sehat, berilmu, cakap, kreatif, mandiri, serta berwarganegara yang demokratis dan bertanggung jawab (Fauzy, 2017:195). Pendidikan karakter merupakan salah satu solusi untuk membentuk pribadi peserta didik yang lebih baik. Pendidikan karakter di sekolah merupakan salah satu program yang dicanangkan oleh pemerintah Indonesia melalui Kemeterian Pendidikan sejak tahun 2010. Program ini dimaskud untuk menanamkan, membentuk dan mengembangkan kembali nilai-nilai karakter bangsa. Karena pendidikan tidak hanya mendidik peserta didiknya untuk menjadi manusia yang cerdas dengan intelektual tinggi saja, akan tetapi juga membangun pribadi dengan akhlak yang mulia, Zubaedi (Ahsanulkhaq, 2016: 26). Pendidikan karakter menjadi usaha sekolah untuk bersama-sama dengan orang tua dan anggota masyarakat untuk membantu peserta didik (Jacobus, 2016:26).

Dalam hal ini penanaman nilai-nilai karakter harus diterapkan kepada peserta didik sehingga mereka dapat menerapkan dalam kehidupannya baik di keluarga, sekolah, masyarakat dan negara sehingga dapat memberikan kontribusi yang positif kepada lingkungannya. Pendidikan karakter bisa tercapai maksimal diperlukan kerjasana antara keluarga, sekolah dan masyarakat (Sumaryati, 2016). Karena pendidikan karakter menjadi salah satu keberhasilan untuk mencapai tujuan pendidikan.(Jacobus, 2016) Adanya pendidikan karakter di sekolah mampu membentuk peserta didik dan memiliki perilaku yang baik dan memiliki pribadi yang baik.

Pembelajaran karakter sebenarnya sudah dilaksanakan sejak dahulu, hanya saja dalam penerapannya dibutuhkan waktu dan usaha yang sungguh-sumgguh, baik dari kepala sekolah, guru, peserta didik, dan semua elemen yang terlibat. Dalam hal ini usaha yang sungguh-sungguh ini berkaitan langsung dengan perbaikan yang berkelanjutan (total quality management) sebagai pendekatan dari manajemen dalam mensukseskan pembelajaran berkarakter.

Pelaksanaan pembelajaran berbasis pendidikan karakter diorientasikan kepada bagaimana; Pertama, siswa memahami materi dan nilainya. Kedua, melihat apa yang dapat dikerjakan setelah mendapat materi dan nilai-nilai pendidikan karakter. Ketiga, dilanjutkan dengan apa yang dirasakan oleh siswa setelah mempelajari materi dan nilai-nilai pendidikan karakter. Ke empat, apa yang mereka lakukan setelah mendapat materi dan nilai-nilai pendidikan karakter. Hanya saja guru biasanya hanya mengajarkan materi dan nilai-nilai karakter hanya pada tataran pengetahuan saja, walaupun ada pula yang melaksanakan hingga tahap sikap (Asmaun, 2009). 


\section{BESTARI}

Vol. 18, No. 1, 2021

p-ISSN 1907-1337; e-ISSN 2807-6532

Total Quality Management sebagai suatu pendekatan diharapkan mampu mewujudkan ketercapaian dari pembelajaran karakter, yaitu dengan fokus pada kepuasan pelanggan, quality, keterlibatan total, komitmen dan perbaikan yang berkelanjutan. TQM merupakan sistem manajemen yang mengangkat kualitas sebagai strategi usaha dan berorientasi pada kepuasan pelanggan dengan melibatkan seluruh anggota Jadi penelitian ini untuk mengetahui implementasi Total Quality Management yang tepat dalam pendidikan, kemudian mengetahui bagaimana pengembangan manajemen pembelajaran karakter religius dengan pendekatan TQM.

\section{REVIEW LITERATUR}

Berdasarkan Penelitian ini, peneliti ini menggunakan beberapa rujukan jurnal yang akan digunakan untuk bahan referensi dari penelitian terdahulu. Selain itu sebagai proses mendapatkan informasi berkaitan dengan judul sebelumnya, maka penulis akan memaparkan, Ada beberapa hasil penelitian atau berhubungan dengan penelitian yang akan dilakukan oleh peneliti, sebagai berikut:

\section{Pengembangan Model Manajemen Berbasis Karakter}

Manajemen adalah menjalankan fungsi perencanaan, pengorganisasian, penggerakan dan pengendalian menjadi suatu rangkaian kegiatan pengambilan keputusan yang bersifat mendasar dan menyeluruh dalam proses pendayagunaan sumberdaya secara efisien disertai penetapan cara pelaksanaannya oleh seluruh jajaran dalam suatu organisasi untuk mencapai suatu tujuan. Syaiful. Kegiatan yang dimaksud disini merupakan tindakan-tindakan yang mana mengacu pada fungsifungsi manajemen. Seorang manajer dalam mencapai tujuan organisasi melibatkan orang lain untuk melaksanakan berbagai tugas yang telah diatur oleh manajer.(Masrokhan, 2013)Oleh karena itu, keterampilan yang dimiliki oleh seorang manajer perlu dikembangkan, baik melalui pengkajian maupun pelatihan. Jika berbicara mengenai perencanaan, pengorganisasian, penggerakan dan pengedalian dapat dikaitan dengan pendidikan karakter maka usaha sadar dan terencana maka dapat mewujudkan suasana belajar dan proses pembelajaran agar peserta didik secara aktif mengembangkan potensi dirinya untuk memiliki kekuatan spiritual keagamaan, pengendalian diri, kepribadian, kecerdasan, akhlak mulia, serta keterampilan yang diperlukan dirinya, masyarakat, bangsa dan Negara.(Depdiknas, 2006)

Sesuai dengan penelitian yang dilakukan oleh Ahmad Zainuri mengenai Pengembangan Model Manajemen Berbasis Karakter (Studi Pengembangan Model Manajemen Berbasis Karakter Di Mts NU Banat) Pada penelitian ini membahas tentang pengembangan model pendidikan karakter melalui pelaksanaan pengembangan manajemen pendidikan melalui perencanaan, pengorganisasian, pelaksanaan, pengawasan, dan 
evaluasi pendidikan karakter. Kemudian dari kekurangan pengembangan model manajemen pendidikan karakter dan pengembangan model manajemen berbasis karakter, yang pertama strategi inklusif, strategi budaya sekolah, startegi eksplorasi diri, strategi penilaian teman sejawat.(Zainuri, 2015)

\section{Implementasi Pendidikan Karakter Melalui Internalisasi Nilai-Nilai Pendidikan}

Karakter dapat dibentuk melalui tahapan pembentukan pola pikir, sikap, tindakan, dan pembiasaan. Maka pendidikan karakter merupakan proses pemberian tuntunan kepada peserta didik untuk menjadi manusia seutuhnya yang berkarakter dalam dimensi pikiran, raga, serta rasa dan karsa. Pendidikan karakter dapat dimaknai dengan pendidikan nilai,pendidikan budi pekerti, pendidikan moral, pendidikan watak, yang bertujuan untuk memberikan keputusan baikburuk, memelihara apa yang baik, dan mewujudkan kebaikan itu dalam kehidupan sehari-hari dengan sepenuh hati

Hasil penelitian ini menunjukkan bahwa implementasi pendidikan karakter di TKIT Al-Hikmah secara umum dilaksanakan melalui internalisasi nilai-nilai pendidikan Islam yang telah dikemas dalam bentuk program sekolah seperti pembiasaan, pengintegrasian di dalam proses pembelajaran yang dilaksanakan melalui program harian dan juga kegiatan-kegiatan lain yang menunjang, yang dilaksanakan satu sampai dua kali dalam setahun. Kemudian didukung oleh keteladanan guru yang selalu memberikan contoh perilaku-perilaku yang baik intervensi lembaga dalam bentuk program dan juga peraturan sekolah serta peran orang tua yang diupayakan untuk selalu sinergis dengan program sekolah. Perbedaan penelitian di atas dengan penelitian yang dilakukan peneliti adalah fokus penelitian. Penelitian di atas fokusnya lebih kepada internalisasi nilai-nilai pendidikan Islam dalam membentuk karakter pada kanak-kanak. Sedangkan penelitian yang dilakukan peneliti implementasi TQM dalam kegiatan keagamaan untuk meningkatkan karakter religius siswa

\section{Implementasi Manajemen Pembelajaran Karakter Berbasis Total Quality Managemen}

Pendidikan budi pekerti yang bertujuan untuk mengembangkan watak dan tarbiat peserta didik dengan cara menghayati nilai-nilai serta keyakinan bahwa kekuatan moral menjadi kekuatan kepercayaan dan kedisiplinan yang dapat menekankan pada ranah yang afektif, kongnitif, dan skill, sesuai dengan peryataan dari Zubaedi (Salim, 2016:30-31). Selain itu Total Quality Management (TQM) merupakan suatu sistem manajemen yang difokuskan kepada seseorang/tenaga kerja, dengan tujuan untuk dapat terus meningkatkan nilai (volue) yang diberikan kepada pelanggan, dengan biaya penciptaan nilai yang lebih rendah dibandingkan nilai tersebut (Supriyanto, 2011:17). Sesuai dengan 


\section{BESTARI}

Vol. 18, No. 1, 2021

p-ISSN 1907-1337; e-ISSN 2807-6532

penelitian yang dilakukan oleh Yoga Anjas Pratama mengenai ImplementasiManajemen Pembelajaran Karakter Berbasis Total Quality Management di SMP Muhammadiyah 3 Yogyakarta dengan Hasil penelitian ini menunjukkan bahwa Pembelajaran karakter dapat diterapkan dengan menggunakan konsep Total Quality Management, yaitu: quality, kepuasaan pelanggan, perbaikan terus menerus, dan menyeluruh disemua komponen organisasi. Selain itu pembelajaran karakter dapat juga diterapakan dalam bentuk proses pembelajaran dikelas yakni dengan menerapkan langkah-langkah pembelajaran (kegiatan pendahuluan, kegiatan inti, dan evaluasi pembelajaran karakter.

Maka dengan demikian dari penelitian relevan diatas yang membedakan yaitu peneliti memfokuskan kepada hal-hal yang terkait didalam implementasi total quality manajemen dalam pengembangan manajemen pembelajaran karakter religius: bagaimana pengembangan manajemen pembelajaran karakter religius dengan pendektan TQM.

\section{METODE}

Penelitian ini merupakan penelitian kepustakaan (library research), penelitian kepustakaan (Harahap, 2014:68) yaitu penelitian yang dilaksanakan dengan menggunakan kepustakaan alias literatur, baik berupa catatan, buku, jurnal maupun laporan hasil penelitian terdahulu (Hasan, 2002: 11). Metode yang digunakan dalam penelitian ini ialah penelitian kualitatif. Penelitian kualitatif merupakan penelitian yang menggunakan pendekatan naturalistik untuk mencari dan menemukan pengertian atau pemahaman tentang fenomena dalam suatu latar yang berkonteks khusus (Moleong, 2014:5).

Partisipan atau sumber data yang digunakan dalam menyelesaikan penelitian kepustakaan ini berasal dari perpustakaan baik berupa buku, artikel, jurnal dan dokumen lainnya (Hadi, 1990). Semua sumber data dokumentasi disini diposisikan sama, tergantung pada sejauh mana korelasinya dengan topik utama penelitian.

Teknik pengumpulan data dalam penelitian ini yaitu dengan melakukan identifikasi wacana dari buku-buku, artikel, makalah, jurnal ataupun informasi lainnya yang berhubungan dengan judul penulisan untuk mencari hal-hal atau variabel yang berupa transkip, catatan, surat kabar, buku, majalah dan lain sebagainya. Maka dari itu, dalam penelitian ini dilakukan langkah-langkah sebagai berikut: (a) Megumpulkan datadata yang ada, baik melalui dokumen, buku-buku, majalah, jurnal; (b) Menganalisa data-data tersebut sehingga bisa menyimpulkan tentang masalah yang dikaji.

Teknik analisis data dalam penelitian ini setelah dilakukannya pengumpulan data, maka data tersebut dianalisis untuk mendapatkan kesimpulan, bentuk teknik dalam teknik analisis data yaitu sebagai berikut: 
a. Analisis Deskriptif

Metode analisis desriptif merupakan usaha untuk menyusun dan mengumpulkan suatu data, kemudian dilakukan analisis terhadap data tersebut (Surakhmad, 1990:139). Analisis deskriptif yaitu data yang dikumpulkan adalah berupa kata-kata atau gambar dan bukan angkaangka. Hal tersebut karena adanya penerapan metode kualitatif. Maka disisi lain juga, yang telah dikumpulkan semuanya berkemungkinan akan menjadi kunci pada yang telah diteliti. Jadi, laporan penelitian mini riset ini nantinya akan berisi kutipan-kutipan data dan pengolahan data untuk memberi gambaran penyajian laporan tersebut.

b. Analisis Isi

Analisis isi yang digunakan dalam penelitian ini adalah content analysis alias analisis isi yang artinya adalah dimana data deskriptif sering hanya dianalisis menurut isinya, oleh karena itu analisis macam ini disebut analisis isi (Suryabrata, 1993).

\section{HASIL PEMBAHASAN}

Konsep Total Qualty Management (TQM)

Menurut Tobin Total Quality Management (TQM) sebagai usaha terintegrasi total untuk mendapatkan manfaat persaingan dengan cara terus-menerus memperbaiki setiap bagian budaya organisasi (Rahmat, 2013:97). Kemudian Total Quality Management (TQM) merupakan suatu pendekatan yang didalam nya menjalankan usaha yang mencoba untuk memaksimumkan daya saing organisasi melalui perbaikan terus-menerus atas produk, jasa, manusia, proses, dan lingkungannya. Santosa menyatakan bahwa Total Quality Management (TQM) merupakan sistem manajemen yang mengangkat kualitas sebagai strategi usaha yang berkonsentrasi pada kepuasan pelanggan dengan melibatkan seluruh anggota organisasi (Fandy dan Tjiptono, 2013:4). TQM secara filosofi dapat dipahami sebagai suatu pendekatan yang menekankan pada adanya suatu usaha perbaikan secara terus menerus dalam memaksimalkan produk, jasa, sumber daya manusia, dan hal-hal yang terkait ruang lingkup visi dan misi organisasi (Septiadi, 2019:38).

Total Quality Management (QTM) merupakan konsep manajemen sekolah dalam penyelenggaraan pendidikan disekolah yang diharapkan dapat memberikan perubahan yang lebih baik sesuai dengan perkembangan, tuntutan, dan dinamika masyarakat dalam menjawab permasalahan-permasalahan pengelolaan pendidikan pada tingkat sekolah. Manajemen mutu ini merupakan sebuah kajian mengenal bagaimana sebuah pendidikan persekolahan harus dikelola secara efektif, efisien, dan berkeadilan untuk mewujudkan mutu pendidikan (Idana, 2017:64). Sedangkan menurut J. Paul Peter dan H. Donnelly dalam Wibowo, menjelaskan Total Quality bahwa TQM adalah komitemen di dalam organisasi untuk memenuhi kepuasan konsumen dengan melanjutkan perbaikan dalam proses bisnis dan produk dan layanan jasa (Suyetno, 2019:68). 


\section{BESTARI}

Vol. 18, No. 1, 2021

p-ISSN 1907-1337; e-ISSN 2807-6532

Penerapan TQM membutuhkan komitmen yang kuat dalam melakukan perbaikan terus-menerus atas produk, jasa, tenaga kerja, proses dan lingkungannya. TQM juga dapat diartikan sebagai perpaduan semua fungsi manajemen, semua bagian dari suatu perusahaan dan semua orang ke dalam falsafah holistik yang dibangun berdasarkan konsep kualitas, teamwork, produktivitas, dan kepuasan konsumen (Nasution, 2010:22). Dalam penerapan Total Quality Management (TQM) di lembaga pendidikan, terdapat lima hal yang harus diperhatikan; yakni adanya fokus kepada pelanggan baik internal maupun eksternal, keterlibatan total, adanya standar mutu, komitmen dan perbaikan mutu berkelanjutan (Endraswari, 2016:304).

Pada dasarnya manajemen kualitas (Quality Management) atau menajemen kualitas terpadu (TQM) didefinisikan sebagai suatu cara meningkatkan performasi secara terus menerus (continuous performance improvement) pada setiap level operasi atau proses, dalam setiap area fungsional dari suatu organisasi, dengan menggunakan semua sumber daya manusia dan modal yang tersedia.(Gaspersz, 2005) Sedangkan menurut Tjiptono Total Quality Management (TQM) merupakan suatu pendekatan dalam menjalankan usaha yang mencoba untuk memaksimumkan daya saing organisasi melalui perbaikan terus menerus atas produk, jasa, manusia, proses, dan lingkungannya.

Singkatnya TQM merupakan sistem manajemen yang mengangkat kualitas sebagai strategi usaha dan berorientasi pada kepuasan pelanggan dengan melibatkan seluruh anggota organisasi. Tujuannya adalah untuk menjamin bahwa pelanggan puas terhadap barang dan jasa yang diberikan, serta menjamin bahwa tidak ada pihak yang dirugikan.(Sallis, 2012)

A. Pembelajaran Karakter Religius

Secara spesifik, pendidikan karakter yang berbasis nilai religius mengacu pada nilai-nilai dasar yang terdapat dalam agama (Islam) (Asranti, 2018:76). Pendidikan karakter menurut John W. Santrock, bahwa "pendidikan karakter merupakan pendekatan langsung untuk pendidikan moral dengan memberi pelajaran kepada peserta didik tentang pengetahuan moral dasar untuk mencegah mereka melakukan perilaku tidak bermoral atau membahayakan bagi diri sendiri maupun orang lain".(Santrock, 2007) Menurut Thomas Linkona bahwa pendidikan karakter mempunyai tujuan bahwa peserta didik mengenal nilai secara kognitif, penghayatan nilai secara afektif, dan akhirnya kepada pengenlan secra nyata (Pratama, 2019:4). Kemudian Menurut Thomas Lickona, karakter berkaitan dengan konsep moral (moral knonwing), sikap moral (moral felling), dan perilaku moral (moral behavior) Berdasarkan ketiga komponen ini dapat dinyatakan bahwa karakter yang baik didukung oleh pengetahuan tentang kebaikan, keinginan untuk berbuat baik, dan melakukan perbuatan kebaikan.

Sedangkan menurut Zubaedi bahwa pendidikan karakter 
merupakan sebuah pendidikan budi pekerti plus yang bertujuan untuk mengembangkan watak dan tabiat peserta didik dengan cara menghayati nilai-nilai dan keyakinan masyarakat sebagai kekuatan moral dalam hidupnya yang dilakukan melalui kejujuran, kepercayaan, kedisiplinan, dan kerja sama yang menekankan pada ranah afektif, kongnitif, dan skill. (Moh Haitami Salim, 2016)

Ada 4 (empat) hal penting dalam pendidikan karakter. Pertama, pendidikan karakter itu sama dengan pendidikan moral dan pendidikan akhlak. Kedua, pendidikan karakter itu bertujuan untuk membentuk pribadi peserta didik supaya menjadi manusia yang baik, warga masyarakat dan warga negara yang baik. Ketiga, pendidikan karakter itu mengandung tiga unsur pokok, yaitu mengetahui kebaikan, mencintai kebaikan, dan melakukan kebaikan. Keempat, karakter peserta didik dapat dipengaruhi oleh guru lewat keteladanannya, seperti cara guru berbicara atau menyampaikan materi, cara guru bertoleransi, dan berbagai hal terkait lainnya. (Aly, 2017)

Kemudian pendidikan karakter dalam penerapnya saat dilingkungan sekolah dapat diterapkan dalam bentuk pembelajaran di sekolah khusunya di kelas yakni dengan pembiasaan pembangunan karakter dengan melalui keteladan serta penanaman nilai-nilai karakter kepada peserta didik.

Pendidikan karakter dalam pendidikan Islam lebih menekankan pada pengembangan individu melalui penanaman akhlak terpuji sehingga mampu menjadikan dirinya sebagi individu yang baik bagi pribadi, Lingkungan dan masyarakat luas. Sedangkan menurut Maunah, terdapat lima tujuan dalam pendidikan karakter, meliputi:

1. Mengembangkan potensi siswa sebagai manusia yang meiliki nilai-nilai karakter bangsa.

2. Penerapan pembiasaan dan perilaku siswa sebagi generasi bangsa yang terpuji dengan nilai-nilai religius.

3. Menanamkan jiwa pemimpin dan tanggung jawab.

4. Mengembangkan kemampuan siswa untuk menjadi individu yang mandiri, kreatif, dan inovatif.

5. Mengembangkan suasana lingkungan yang nyaman dan tentram untuk belajar.

Pendidikan karakter yang berbasis nilai religius mengacu pada nilai-nilai dasar yang terdapat dalam agama (Islam). Ada beberapa sumber yang menyatakan bahwa nilai-nilai karakter memiliki prinsip, tetapi yang menjadi prinsip dasar pendidikan karakter yang berasal dari keteladanan Rasulullah yang terwujud dalam sikap dan perilaku seharihari beliau, yakni shiddîq (jujur), amânah (dipercaya), tabligh (menyampaikan dengan transparan), fathanah (cerdas).(Hidayatullah, 2010) Untuk membentuk kepribadian peserta didik, penanaman nilainilai religius sangatlah penting untuk dijadikan pertimbangan bagi stakeholder pendidikan, terutama bagi orang tua dan guru yang terlibat langsung dalam proses pembentukan karakter. Pendidikan agama 


\section{BESTARI}

Vol. 18, No. 1, 2021

p-ISSN 1907-1337; e-ISSN 2807-6532

mendorong dan menjamin penguasaan dan ilmu pengetahuan dalam berbagai dsiplin di sekolah (Ilahi, 2014:4).

Tentunya karakter religius sangat dibutuhkan oleh peserta didik unuk menghadapi perubahan zaman dengan degradasi moral, diharapkan mampu memiliki perilaku baik sesuai dengan ketentu dan ketetapan dari agama. Pandangan hidup ialah "konsep nilai yang dimiliki seseorang atau sekelompok orang mengenai kehidupan" nilai-nilai adalah sesuatu yang dipandang berharga dalam kehidupan manusia, yang mempengaruhi sikap hidupnya (Nashir, 2013). Maka dengan demikian pembelajaran karakter merupakan sebuah proses pentrasferan, pembiasaan, ataupun pembentukan sebuah nilai-nilai karakter yang dilakukan oleh tenaga pendidik terhadap peserta didik dalam suat lingkungan belajar. Menurut Ahmad Tafsir mengemukakan bahwa proses pengintergrasian pendidikan agama ke dalam pembelajaran dapat dilakukan dengan cara atau langkah-langkah sebagai berikut: (1) pengintergrasian materi pelajaran; (2) pengintergrasian proses; (3) pengintergrasian pemilihan bahan ajar dan (4) pengintergrasian pemilihan media (Tafsir, 2009). Menurut P-O-A-C ada model, seperti; (Planning, Organizing, Actuating, and Controling). Namun m, pengertian tersebut mengalami transformasi sekitar tahun (1914), dimana seorang ahli bernama Henry Fayol yang berkebangsaan Perancis mengatakan bahwa manajemen melaksanakan lima fungsi utama, yaitu merencanakan (plan) aktivitas yang akan dilakukan, kemudian mengorganisasikan (organize) untuk mencapai rencana tersebut. Selanjutnya mengarahkan (direct) sumber daya yang dimiliki untuk melaksanakan rencana dan memimpin sumber dayanya (leading) (Sulastri, 2012:10).

Implementasi Total Quality Management dalam pembelajaran karakter religiusImplementasi merupakan suatu proses penerapan ide, konsep, kebijakan atau inovasi dalam suatu tindakan praktis sehingga memberikan dampak, baik berupa perubahan pengetahuan, keterampilan, maupun nilai, dan sikap. Implementasi diartikan sebagai suatu proses penerapan ide, konsep dan kebijakan tertentu dalam suatu aktivitas sehingga menghasilkan kemampuan tertentu sebagai hasil intraksi dengan lingkungan (Kompri, 2014:172).

Total Quality Management (TQM) merupakan suatu sistem manajemen yang difokuskan kepada seseorang/tenaga kerja, dengan tujuan untuk dapat terus meningkatkan nilai yang diberikan kepada pelanggan, dengan biaya penciptaan nilai yang lebih rendah dibandingkan nilai tersebut (Supriyanto, 2011:17). Dalam Total Quality Management (TQM), pembelajaran karakter dapat dipahami sebagai pendekatan yang mampu memaksiamalkan kinerja, tenaga kerja, mutu, produk, serta lingkungan dala mencapai tujuan pembelajaran karakter dengan upaya perbaikan secara terus menurus dalam berkelanjutan.

Selain itu menurut Aminatul Zahroh (2016), bahwa Total Quality Management juga memiliki beberapa konsep, yakni: (1) Quality; (2) 
Kepuasan pelanggan; (3) Perbaikan terus-menerus; dan (4) menyeluruh disemua komponen organisasi. Dari beberapa konsep pembelajaran karakter dapat dijelaskan sebagai berikut:

1. Quality, kualiatas ini yang dimaksud ialah output atau outcome, setelah dilakukanya pembelajaran karakter atau penanaman nilainilai karakter pada peserta didik melalui pembelajaran. Output dan outcome merupakan implementasi nilai-nilai karakter yang dilakukan peserta didik dalam kehidupan sehari-hari. Quality dalam pembelajaran karakter religius bahwa terwujudnya bentuk penanaman karakter religius melalui beberapa kegiatan yang ada di sekolah sehingga berpengaruh terhadap quality, output, outcome pada diri peserta didik. Nilai-nilai karakter religius yang ditanamkan melalui kegiatan sekolah seperti Penciptaan suasana religius, penciptaan suasana religius merupakan upaya untuk mengkondisikan suasana dengan nilai-nilai dan perilaku religius (keagamaan) (Hilyah Ashoumi, 2016).

2. Kepuasan pelangan, Kepuasan pelanggan dalam pembelajaran karakter dapat berupa kepuasan terhadap hasil yang dicapai, seperti: kepuasan orang tua terhadap perubahan sikap/karakter yang dimiliki oleh seorang peserta didik yang diperoleh dari hasil pembelajaran. Untuk mencapai kepuasan pelanggan maka pendidik harus berfokus pada kepuasaan pelanggan baik itu pelanggan eksternal maupun internal. Pelanggan eksternal ialah pelanggan yang menentukan mutu lulusan sedangkan pelanggan internal ialah pelanggan yang menentukan mutu, proses, dan lingkungan yang berhubungan dengan lulusan.

Memberikan kepuasan kepada pelanggan dalam bentuk pelayananpelayanan yang diberikan oleh pihak sekolah terhadap peseta didik. Pelayanan tersebut seperti pelayanan sarana prasarana, media pembelajaran, yang mendukung dari pelaksananya pembelajaran karakter. Seperti perpustakaan, tempat ibadah yang bersifat religi.

3. Perbaikan terus-menerus. Konsep dasar kualitas adalah segala sesuatu dapat diperbaiki. Kualitas didasarkan pada konsep bahwa setiap proses dapat diperbaiki dan tidak ada proses yang sempurna (Sabda, 2002:37). Proses perbaikan ini ditujukan untuk menghasilkan hasil yang lebih baik dengan menggunakan kerangka metode pemecahan masalah. Perbaikan terus-menerus dalam pembelajaran karakter dimaksudkan untuk meningkatkan mutu capaian dengan cara perbaikan secara terusmenerus dalam pembelajaran, seperti: perbaikan dalam hal penyampaian bahan ajar yaitu dengan menggunakan berbagai macam media yang tepat guna, mengontrol, mempersiapkan, dan memperbaiki lingkungan belajar secara berkala, menjadikan proses pembelajaran menjadi aktif dan menjadi teladan bagi peserta didik dalam pengembangan karakter.

4. Menyeluruh disemua komponen organisasi. Yang dimaksud dengan menyeluruh disemua komponan organisasi ialah perbaikan secara 


\section{BESTARI}

Vol. 18, No. 1, 2021

p-ISSN 1907-1337; e-ISSN 2807-6532

menyeluruh/tidak hanya terfokus pada pembelajaran saja. Perbaikan secara menyeluruh melibatkan semua komponen organisasi baik dari dalam maupun luar lembaga pendidikan. Adanya perubahan kurikulum KTSP menjadi K13, adanya penekanan pada kegiatan intrakuikuler, kokurikuler, dan ekstrakurikuler, perbaikan secara dan prasarana lembaga pendidikan, dan kebijakan pemerintah terhadap pembangunan karakter.

Rangkaian kegiatan pembelajaran karakter merupakan proses dari pembelajaran karakter yang berlangsung di dalam maupun di luar kelas yang bertujuan untuk menjadikan peserta didik dapat menguasai kopetensi-kopetensi seperti materi, mengenal, menyadari/peduli, serta meninterrnalisasikan kedalam nilai-nilai dan menjadikannya perilaku.(Endah Sulistyowati, 2012) Pembentukkan karakter religius menjadi karakaker yang kuat, dalam pembinaan ini peran strategi pendidik (guru) semakin nyata dan sangat dibutuhkan baik dalam fungsi mengajar, membiming atau mengarahkan, dan membina, guru tetap harus menggunakan sifat Allah rabbul alamin, tuhan semesta alam senantiasa melimpahkan kasih sayang dan cintanya kepada mahluk-Nya. Maka dengan sifat Allah ini lah pendidik (guru) mengajar, membimbing dan mengarahkan murid-muridnya.

Pembelajaran karakter berbasis Total Quality Management seperti yang telah dijelaskan sebelumnya, maka dapat diterapkan juga dalam bentuk proses pembelajaran. Pembelajaran karakter dapat diterapkan oleh seorang guru dalam pembelajaran dengan menggunakan pendekatan Total Quality Management. seorang guru dapat menemakan nilai-nilai karakter dalam pembelajaran. Terdapat tiga hal yang dapat dilakukan oleh guru dalam penanaman nilai-nilai karakter, sebagai berikut: (1) Perencanaan pembelajaran karakter; (2) Pembelajaran karakter berbasis siswa; (3) Evaluasi pembelajaran karakter (Pratama, 2019:8).

a. Perencanaan pembelajaran karakter

Perencanaan pembelajaran merupakan suatu kompetensi pedagogik yang wajib dimiliki oleh setiap guru atau tenaga pendidik. Pada tahap perencanaan ini guru menyusun silabus, RPP, dan bahan ajar dimana silabus, RPP, dan bahan ajar tersebut dirancang sedemikian rupa agar muatan kegiatan pembelajaran yang memfasilitasi atau berwawasan pendidikan karakter. Pendidikan karakter religius merupakan pengetahuan yang bersifat religius, memberikan pembelajaran yang bersifat religius ke peserta didik, guru mampu merancang silabus, RPP, serta bahan ajar yang bersifat religious.

Dalam hal ini setidaknya ada tiga komponen modifikasi yang dilakukan agar silabus, RPP, dan bahan ajar memfasilitasi pendidikan karakter. Ketiga komponen tersebut, sebagai berikut: (1) Adanya penambahan atau modifikasi kegiatan pembelajaran sehingga kegiatan pembelajaran tersebut dapat mengembangkan karakter peserta didik; (2) Adanya penambahan dan/atau modifikasi pada indikator pencapaian 
sehingga indikator tersebut dapat mengukur pencapaian belajar dan karakter peserta didik; (3) Adanya penambahan dan/atau modifikasi pada teknik penilaian sehingga teknik penilaian tersebut dapat mengukur perkembangan karakter peserta didik.

b. Pembelajaran karakter berbasis siswa

Pembelajaran berbasis siswa (PBS) merupakan proses pembelajaran yang ditekankan pada keaktifan siswa yang meliputi aspek kognitif, afektif, dan psikomotorik, dan dalam pembelajaran bersifat berpusat pada siswa(Gunawan, 2012). Dalam pembelajaran karakter peserta didik menjadi faktor utama, dengan menepatkan siswa dalam proses pembelajaran dan menjadi subjek belajar yang memiliki potensi, dan proses pembelajaran diarahkan untuk memberikan pengalaman belajar agar siswa dapat mengembangkan seluruh potensi yang dimilikinya. Tidak lepas dari karakter religius pembelajaran ini memiliki langkah yang mampu melaksanakan pembelajaran karakter yang berbasis siswa, meliputi: adanya kegiatan pendahuluan, kegiatan inti (ekslorasi, elaborasi, konfirmasi) kemudian kegiatan penutup.

1) Kegiatan pendahuluan

Pada kegiatan pendahuluan guru menyiapkan peserta didik secara psikis dan fisik untuk mengikuti proses pembelajaran dengan mengajukan sejumlah pertanyaan yang mengaitkan materi sebelumnya dengan materi yang akan dipelajari, menjelaskan tentang tujuan pembelajaran atau kompetensi dasar yang akan dicapai, dan menyampaikan cakupan materi dan penjelasan uraian kegiatan sesuai dengan silabus.

\section{2) Kegiatan inti (ekplorasi)}

Kegiatan ini seorang guru melibatakan atau memerintahkan peserta didik untuk mencari sebuah informasi dengan sebanyakbanyaknya sesuai dengan topic yang dipelajari, nilai yangditanamkan untuk kegiaan ini yaitu; kemandirian, berfokir logis, kreatif dan kerjasama. Kemudian guru menggunakan berbagai macam bentuk pendekatan pembelajaran, media pembelajaran, dan sumber belajar lainnya, nilai yang diatanamkan yaitu kreatif dan kerja keras.

Selanjutnya guru memfasilitasi terjadinya interaksi antara peserta didik dengan peserta didik dan peserta didik dengan guru, lingkungan, dan sumber belajar lainya, kemudian Guru memfasilitasi peserta didik untuk melakukan percobaan dilaboratorium, studio atau lapangan, nilai yang ditanamkan yaitu: (mandiri, kerja sama, kerja keras).

3) Kegiatan inti (elaborasi)

Pada kegiatan elaborasi ini guru membiasakan peserta didik untuk membaca dan menulis melalui tugas-tugas tertentu yang bermakna, nilai yang ditanamkan yaitu: (cinta ilmu, kreatif, dan logis). Guru memfasilitasi peserta didik melalui pemberian tugas, diskusi, dan lain-lain untuk memunculkan gagasan baru baik secara lisan maupun tertulis, nilai yang ditanamkan yaitu: (kreatif, percaya diri, kritis, saling 


\section{BESTARI}

Vol. 18, No. 1, 2021

p-ISSN 1907-1337; e-ISSN 2807-6532

menghargai, santun). Kemudian Guru memfasilitasi peserta didik dalam pembelajaran kooperatif dan kolaboratif, nilai yang ditanamkan berupa: (kerja sama, saling menghargai, tanggungjawab).

4) Kegiatan inti (konfirmasi)

Pada kegiatan konfirmasi ini guru memberikan umpan balik positif dan penguatan dalam bentuk lisan, tulisan, isyarat, maupun hadiah terhadap keberhasilan peserta didik, nilai yang ditanamkan yaitu: (saling menghargai, percaya diri, santun, kritis, logis).Guru memberikan konfirmasi terhadap hasil ekplorasi dan elaborasi peserta didik dari berbagai sumber, nilai yang akan ditanamkan berupa: nilai percaya diri, logis, kritis.

Selanjutnya guru memfasilitasi peserta didik untuk melakukan refleksi guna memperoleh pengalaman dari pembelajaran yang telah dilakukan, nilai yang ditanamkan yaitu: (memahami kelebihan dan kekurangan diri sendiri). Guru memfasilitasi peserta didik agar dapat lebih jauh/dalam/luas dalam hal pengkajian dan pemrolehan pengetahuan, keterampilan, dan sikap, nilai yang ditanamkan yaitu peduli, santun, cinta ilmu, percaya diri.

5) Kegiatan penutup

Pada kegiatan penutup ini guru bersama peserta didik atau secara sendiri membuat sebuah simpulan dari pembelajaran yang dilakukan, nilai yang ditanamkan yaitu: (mandiri, kerjasama, kritis, logis). Guru melakukan penilaian atau refleksi terhadap kegiatan yang telah dilakukansecara konsisten dan terprogram, nilai yang ditanamkan yaitu: nilai jujur, mengetahui kekurangan dan kelebihan.

Selanjutnya guru memberikan feedback (umpan balik) kepada peserta didik mengenai proses dan hasil pembelajaran yang telah dilakukan, nilai yang ditanamkan yaitu: (saling menghargai, percaya diri, santun, kritis, logis). Kemudian guru merencanakan sebuah kegiatan tindak lanjut yang berupa pembelajaran remedi, program pengayaan, layanan koseling atau memberikan tugas secara individual ataupun kelompok sesuai dengan hasil belajar yang diperoleh peserta didik serta guru menyampaikan rencana pembelajaran yang akan dilakukan pada pertemuan berikutnya.

Selain itu guru-guru juga menggunakan berbagai metode mengajar dengan menggunakan metode, seperti: demokrasi, diskusi dan kemudian dapat memanfaatkan berbagai media pembelajaran, seperti film, video, audio, leptop dll. Dapat dilihat dalam penerapan pembelajaran karakter religius dengan menjelaskan kepada peserta didik terkait tata sholat dan wudhu, guru bisa menjelaskan terkait tata cara dengan memakai media gambar-gambar atau poster untuk memperjelas penjelasannya. Kemudian guru menggunakan metode ceramah dan menggunakan metode demostrasi ketika peserta didik mempraktekan tata cara sholat dan wudhu.

c. Evaluasi pembelajaran karakter 
Evaluasi pembelajaran merupakan kegiatan yang dilakukan untuk mengetahui perubahan perilaku dan pembentukan kompetensi pada peserta didik. Evaluasi pembelajaran ini dapat berupa: penilaian kelas, tes kemampuan dasar, penilaian akhir satuan pendidikan dan sertifikasi perbandingan serta penilaian program.

Evaluasi pembelajaran sebaiknya dilakukan tidak hanya untuk mengukur pencapaian akademik tetapi juga keperibadian siswa atau peserta didik. Diantara teknik-teknik yang dapat dilakukan untuk penilaian akademik maupun keperibadian siswa atau peserta didik, sebagai berikut: (1) Observasi (dengan lembar obserbasi/pengamatan); (2) Penilaian diri (dengan lembar penilaian diri/kuisioner; (3) Penilaian antar teman (lembar penilaian antar teman). Dengan demikian pembelajaran karakter religius dapat di nilai, bagaimana karakter religius itu mampu memberikan penilaian yang baik melalui penilaian yang diberikan oleh pihak sekolah, berupa rapor kepada siswa, kemudian adanya rapat mengenai pembelajaran/kendalakendala pembelajaran selama satu semester dll.

Dalam pendidikan karakter, Lickona (1992) menekankan pentingnya tiga komponen karakter yang baik (components of good character) yaitu moral knowing atau pengetahuan tentang moral, moral feeling atau perasaan tentang mental dan moral action atau perbuatan moral. Hal ini diperlukan agar anak mampu memahami, merasakan dan mengerjakan sekaligus nilai-nilai kebajikan.

1) Moral knowing merupakan penalaran moral atau pemikiran moral atau pertimbangan moral hal karakter/watak. Konsep moral kesadaran, moral pengetahuan nilai moral pandangan ke depan penalaran moral pengambilan keputusan pengetahuan diri sikap moral kata hati rasa percaya diri, moral kemampuan kemauan kebiasaan yang penting untuk diajarkan, terdiri dari enam hal, yaitu:

a. Moral awareness (kesadaran moral) hidup dalam lingkungan yang mana orang-orang melek moral (conditioning). Hasil belajar dapat mengidentifikasi isu moral dari sebuah peristiwa. Dapat mengeplisitkan isu moral dari sebuah peristiwa

b. Knowing moral values (mengetahui nilai-nilai moral). Pengalaman belajar: Melalui pengalaman belajar kognitif (mengingat, memahami, menerapkan). Hasil belajar dapat menyebutkan nilai moral tertentu. Menginterpretasi nilai moral dari suatu peristiwa atau komunikasi.

c. perspective taking. Pengalaman belajar dengan mempraktikkan pengambilan perspektif (sudut pandang) orang lain pada para siswa. Menganalisis sudut pandang orang lain atau budaya lain. Hasil belajar: menginterpretasi secara objektif perasaan dan pikiran orang lain. Menerjemahkan perasaan dan pikiran orang lain. 


\section{BESTARI}

Vol. 18, No. 1, 2021

p-ISSN 1907-1337; e-ISSN 2807-6532

d. moral reasoning. Pengalaman belajar: melalui belajar kognitif (analisis) tentang perbuatan bermoral. Hasil belajar dapat menyediakan alasan atas semua perbuatan moral. Menjelaskan alasan atas suatu perbuatan moral.

e. decision making. Pengalaman belajar dapat mengalami secara simultif konflik atau dilema nilai, dapat juga konflik nilai yang dialami orang lain, kemudian membuat putusan nilai, dan mengkajinya. Hasil belajar: memiliki putusan nilai lengkap dengan konsekuensinya yang sudah terkaji secara baik, atas konflik nilai yang tersedia.

f. self knowledge. Pengalaman belajar dapat dilakukan dengan meminta siswa membuat jurnal etis/akhlak/budi pekerti dengan mencatat kejadian-kejadian moral dalam kehidupan mereka. Apa saja respon-respon mereka dalam kejadian moral tersebut, dan adakah respon ini dapat dipertanggung jawabkan secara etis. Hasil belajar: perkembangan kejujuran individu dalam melihat diri sendiri.

2) Moral feeling adalah aspek yang lain yang harus ditanamkan kepada anak yang merupakan sumber energi dari diri manusia untuk bertindak sesuai dengan prinsip-prinsip moral. Dalam hal ini lebih menekankan pada kesadaran akan hal-hal yang baik dan tidak baik.

a. Hati Nurani (conscience), nurani memiliki dua sisi: sisi kognitif yaitu pengetahuan tentang apa yang baik dan sisi emosional yaitu merasa wajib melakukan apa yang baik. Pengalaman belajar: berlatih menghadapi kasus-kasus yang menuntut individu mengekspresikan nuraninya melalui stimulasi yang mendorong individu mengekspresikan nuraninya dan diskusi tentang kasuskasus penggunaan atau pengabaian nurani. Hasil belajar: kapasitas untuk merasa bersalah dan merasa wajib untuk perbuatan moral. Pada tataran lebih rendah ekspresi-ekspresi nurani ini melalui kata-kata.

b. Self Esteem (percaya diri), yakni kemampuan merasa bermartabat karena memiliki kebaikan atau nilai luhur. Pengalaman belajar: perbuatan baik yang dilakukan seseorang sering membuat orang merasa senang atau bahagia karena melakukannya. 5 Hasil belajar: individu yang puas dengan dirinya sendiri dalaam perbuatan baik dan sebaliknya merasa tidak senang atau tidak bahagia dalam perilaku buruk.

c. Empathy (merasakan penderitaan orang lain), yaitu identifikasi diri pada keadaan orang lain atau pengalaman tidak langsung Pengalaman belajar: dapat melatih melakukan empati di bawah bimbingan guru, setelah berlatih guru dapat membimbing siswa untuk mendiskusikannya. Hasil belajar: mengungkapkan apa yang 
dirasakan orang lain, bertoleransi, dan menghargai perbedaan sikap.

d. Loving the good (mencintai kebenaran), yaitu ketertarikan sejati atau tulus pada kebaikan. Pengalaman belajar: para guru dapat menerapkan dan mengembangkan program-program peer tutoring dan pelayanan masyarakat di sekolah Hasil belajar: upaya-upaya pribadi dan dalam kelompok untuk berbuat baik

e. Self control (mampu mengontrol diri) yakni emosi dapat menenggelamkan penalaran. Inilah pentingnya kontrol diri adalah sebuah kebajikan moral yang dapat membantu kita berperilaku moral/bermoral dan tidak bermoral. Pengalaman belajar: dalam bentuk menolak kesenangan atau kebencian demi kebaikan Hasil belajar: tekun belajar/bekerja, menunda kesenangan, tugas-tugas belajar diselesaikan dengan baik. f) Humility (kerendahan hati). Definisi: sisi afektif dari pengetahuan diri, yang terdiri dari keterbukaan yang sejati pada kebenaran dan kemauan untuk bertindak memperbaiki kesalahan-kesalahan kita. Pengalaman belajar: berlatih terbuka terhadap kebenaran, dari manapun sumbernya, dan mau memperbaiki kesalahan-kesalahan diri sendiri. 6 Hasil belajar: mengakui kebenaran pendapat orang lain, mengaku bersalah jika melakukan kesalahan, dan memberikan penghargaan terhadap pendapat orang lain.

f. Moral Action adalah bagaimana membuat pengetahuan moral dapat diwujudkan menjadi tindakan nyata. Perilaku moral merupakan kemampuan untuk melakukan keputusan dan perasaan moral kedalam perilaku-perilaku nyata Perbuatan tindakan moral ini merupakan hasil (outcome) dari dua komponen karakter lainya. Untuk memahami apa yang mendorong seseorang dalam perbuatan yang baik (act morally) maka harus dilihat tiga aspek lain dari karakter, yaitu kompetensi (competence), keinginan (will) dan kebiasaan (habit).

g. Kompetensi (Competence), yaitu kompetensi moral adalah kemampuan mengubah putusan dan perasaan moral menjadi tindakan moral yang efektif. Pengalaman belajar menurut Ervin Staub adalah di mana anak-anak memiliki pengalaman yang terbimbing dalam role playing. Dalam serangkaian situasi bermasalah, yang di dalamnya seorang anak membantu anak lainnya pada waktu berikutnya lebih mungkin (dibandingkan dengan anak-anak tanpa pengalaman yang demikian) untuk menyelidiki suara tangisan seorang anak dalam ruangan. Hasil belajar: kemampuan melaksanakan tindakan moral, berbuat baik dan membantu orang lain untuk berbuat baik.

h. Keinginan (will), yaitu inti dari keberanian moral Pengalaman belajar: siswa diminta untuk mencatat kemauan-kemauan moral apa saja yang tidak dipenuhinya, selanjutnya adalah praktikpraktik mewujudkan kemampuan tersebut. Hasil belajar: individu 
yang berupaya memiliki kemauan melakukan tindakan moral, berbuat adil sekalipun terhadap orang yang tidak disukainya. Berdisiplin melakukan suatu tindakan moral.

i. Kebiasaan (habit), yaitumelakukan hal-hal yang baik oleh kekuatan kebiasaan pengalaman belajar: anak-anak membutuhkan sebagai bagian dari pendidikan moral mereka, banyak kesempatan untuk mengmbangkan kebiasaan baik, banyak praktik menjadi orang baik. Hasil belajar: kebiasaan dalam hal tertentu (biasa sopan santun, tolong menolong, adil, dan lain-lain.

Pada akhirnya penerapan Total Quality Management dalam pembelajaran karakter religius bertumpu pada proses dimana dalam proses pembelajaran dibutuhkan komitmen dan perbaikan terus menerus baik pada proses, lingkungan sekitar, pribadi guru dll, yang mendukung dalam penanaman dan pembentukan karakter religius kepada peserta didik.

\section{DISKUSI}

Implementasi total quality management dalam pengembangan manajemen pembelajaran karakter religius. Memberikan pemahaman bahwa Pembelajaran karakter religius merupakan sebuah pembelajaran karakter yang menanamkan nilai-nilai religius dengan menggunakan konsep Total Quality Management, yaitu: quality, kepuasan pelanggan, perbaikan terus-menurus, dan menyeluruh disemua komponen organisasi. Bagaimana nilai-nilai dalam karakter religius tersebut dapat diimplemtasikan kedalam pembelajaran karakter di sekolah. Hasil dari penelitian ini adalah pembelajaran karakter religius dapat seorang guru dapat menemakan nilai-nilai karakter dalam pembelajaran.

Penelitian ini sedikit berbeda dengan penelitian-penelitian sebelumnya karena penelitian ini menggabungkan dua variabel menjadi satu untuk mewujudkan tujuan pendidikan nasional. Kemudian, penelitian ini membahas tentang bagaimana manajemen pembelajaran karakter religius diekolah harus dikelolah dan dijalankan secara efektif, efisien agar terwujudnya mutu pendidikan yang baik.

Dari hasil tersebut yang perlu dilakukan adalah setiap lembaga pendidikan sekolah harus melakukan inovasi, kemudian seorang tenaga pendidik harus mampu melakukan inovasi terhadap pembelajaran, melakukan perbaikan dan perubahan secara terarah, dan mempraktikkan $T Q M$, akan mengalami siklus perbaikan secara terus-menerus. Semangat tersebut akan menciptakan sebuah upaya sadar untuk menganalisis apa yang sedang dikerjakan dan merencanakan perbaikan untuk kedepannya. 


\section{SIMPULAN}

Berdasarkan dari pembahasan yang telah dibahas diatas, maka dapat ditarik kesimpulan bagi peneliti, yaitu: Total Quality Management (TQM) merupakan suatu sistem manajemen yang terfokuskan kepada seseorang/tenaga kerja, dengan tujuan untuk dapat terus meningkatkan nilai yang diberikan kepada pelanggan. Kemudian dalam Total Quality Management (TQM), pembelajaran karakter dapat dipahami sebagai pendekatan yang mampu memaksiamalkan kinerja, tenaga kerja, mutu, produk, serta lingkungan untuk mencapai tujuan pembelajaran karakter dengan upaya perbaikan secara terus menurus dalam berkelanjutan

Pembelajaran karakter dapat diterapkan dengan menggunakan konsep Total Quality Management, yaitu: quality, kepuasaan pelanggan, perbaikan terus menerus, dan menyeluruh disemua komponen organisasi. Selain itu pembelajaran karakter dapat juga diterapakan dalam bentuk proses pembelajaran dikelas yakni dengan menerapkan langkah-langkah pembelajaran (kegiatan pendahuluan, kegiatan inti, dan evaluasi pembelajaran karakter.

\section{DAFTAR PUSTAKA}

Ahsanulkhaq, M. (2019). Membentuk Karakter Religius Peserta Didik Melalui Metode Pembiasaan. Jurnal Prakarsa Paedagogia, 2(1).

Aly, A. (2017). Pengembangan Pembelajaran KarakterBerbasisSoft Skills Di Perguruan Tinggi. Shraqi, Volume 1(No 1).

Arsanti, M. (2018). Pengembangan Bahan Ajar Mata Kuliah Penulisan Kreatif Bermuatan Nilai-Nilai Pendidikan Karakter Religius Bagi Mahasiswa Prodi PBSI, FKIP, UNISSULA. Jurnal Kredo, Vol 1(No 2).

Asiatik Afrik Rozana, Abdul Hamid Wahid, dan C. M. (2018). Smart Parenting Demokratis dalam Membangun Karakter Anak. Al-Athfal: Jurnal Pendidikan Anak, Vol.4(Nol. 1).

Asmaun, S. (2009). Mewujudkan Budaya Religius di Sekolah. UIN Maliki Press.

Chaplain, J. . (1999). Ditionary of Psychology. Raja Grafindo Utama.

Chowdhury, M. (2016). Emphasizing Morals, Values, Ethics, And Character Education In Science Education And Science Teaching. The Malaysian Online Journal of Educational Science, 4(2).

Depdiknas. (2006). Undang-Undang Sistem Pendidikan Nasional. Pustaka Pelajar.

Dharma, K. (2012). Pendidikan Karakter Kajian Teori dan Praktik di Sekolah. Remaja Rosda Karya.

Endah Sulistyowati. (2012). Implementasi Kurikulum Pendidikan Karakter. Citra Aji Parama.

Fauzi, A. (2017). Internalization Of Religious Values To Grow Student Character In Public School. Proceeding International Conference On Islamic Education (Icied) "Innovations, Approaches, Challenges, 
And The Future" Fakultas Ilmu Tarbiyah Dan Keguruan Universitas Islam Negeri (Uin) Maulana Malik Ibrahim Malang, Vol. 2.

Gaspersz, V. (2005). Total Quality Management. PT. Gramedia Pustaka Utama.

Gunawan, H. (2012). Pendidikan Karakter Konsep dan Implementasi. Alfabeta.

Hidayatullah, M. F. (2010). Pendidikan Karakter: Membangun Peradaban Bangsa. Yuma Pustaka.

Hilyah Ashoumi, M. P. . (2016). Pendayagunaan Lingkungan Sekolah Religius Untuk Memaksimalkan Pencapaian Kurikulum PAI. Dosen PAI Fakultas Agama Islam UN WAHA Tambakberas Jombang, Dinamika, Vol,1(No, 1).

Ilahi, M. T. (2014). Gagalnya pendidikan karakter. AR-RUZZ MEDIA.

Islam, S. (2017). Karakteristik Pendidikan Karakter; Menjawab Tantangan Multidimensional melalui Implementasi Kurikulum 2013. Edureligia, Vol. 1(No. 1).

Jacobus, E. C. H. en A. (2016). Implementasi Pendidikan Karakter di Sekolah Melalui Keteladanan dan Pembahasan. Pendidikan Dasar Indonesia, 1(2).

Masrokhan, P. (2013). Manajemen Mutu Sekolah. Ar-Ruzz Media.

Nashir, H. (2013). Pendidikan Karakter Berbasis Agama dan Budaya. Multi Presindo.

Nasution, I. (2010). Manajemen Mutu Terpadu (Total Quality Management. Ghalia Indonesia.

Pratama, Y. A. (2019a). Implementasi Manajemen Pembelajaran Karakter Berbasis Total Quality Management di SMP Muhammadiyah 3 Yogyakarta. Manajemen Pendidikan Islam, 4(1).

Pratama, Y. A. (2019b). Implementasi Manajemen Pembelajaran Karakter Berbasis Total Quality Management Di SMP Muhammadiyah 3 Yogyakarta. Jurnal Manajemen Pendidikan Islam, 4(1).

Saefullah, A. S. (2019). Implementasi Pendidikan Karakter Melalui Internalisasi Nilai-Nilai Pendidikan Islam Di TKIT Al- Hikmah. GARUDA Garba Rujukan Digital, Vol. 3(No 2).

Salim, Moh Haitami. (2016). Pendidikan Karakter: Konsepsi dan Implementasinya Secara Terpadu di Lingkungan Keluarga, Sekolah, Perguruan Tinggi, dan Masyarakat. AR-RUZZ MEDIA.

Salim, Mohammad Haitami. (2016). Pendidikan Karakter: Konsepsi dan Implementasinya Secara Terpadu di Lingkungan Keluarga, Sekolah, Perguruan Tinggi, dan Masyarakat,. AR-RUZZ MEDIA.

Sallis, E. (2012). Total Quality Management in Education. Ircisod,.

Santrock, J. W. (2007). Psikologi Pendidikan. Terj. Tri Wibowo B.S., Kencana, edisi 2.

Septiadi, W. (2019). Tinjauan Total Quality Management (TQM) Pada Lembaga Pendidikan Islam. Nidhomul Haq: Jurnal Manajemen 


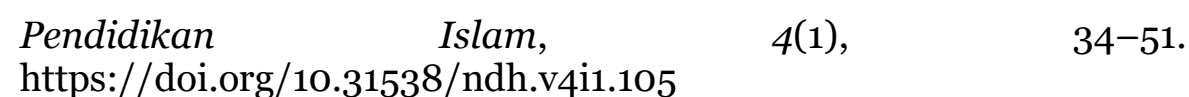

Sulastri, L. (2012). Manajemen Sebuah Pengantar. La Goods Publishing. Sumaryati. (2016). Manajemen Pendidikan Karakter. Tarbawiyah, 13(2).

Supriyanto, A. (2011). Implementasi Total Quality Managementdalam Sistem Manajemen Mutu Pembelajaran Di Institusi Pendidikan. Cakrawala Pendidikan, $X X X$ (No 1).

Suyetno. (2019). Peningkatan Sumberdaya Manusia Melalui PenerapanTotal Quality Management. Jurnal Akuntansi, Ekonomi Dan Manajemen Bisnis, 4(2).

Tafsir, A. (2009). Pendidikan Budi Pekerti. Maestro.

Tjiptono, F. dan A. D. (2013). Total Quality Management. Andi Offset.

Yuri dan Rahmat. (2013). Manajemen Kualitas Total dalam Perspektif Teknik Industri. PT Indeks.

Zainuri, A. (2015). Pengembangan Model Manajemen Berbasis Karakter (Studi Pengembangan Model Manajemen Berbasis Karakter Di MTS NU Banat). QualiTy, 3(2). 